\title{
Molecular identification and antibiotic resistance profiling of Salmonella species isolated from chickens in eastern Turkey
}

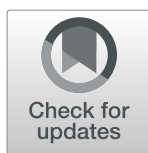

\author{
Aydogan Arkali ${ }^{1}$ and Burhan Çetinkaya ${ }^{2^{*}}$
}

\begin{abstract}
Background: The aim of this study was to obtain quantitative data about the frequency, genotypic characterization and antibiotic resistance profiling of Salmonella agents in chicken flocks located in eastern Turkey.

Results: Feces samples representing at least $20 \%$ of the flock area were collected via sock swabs from commercial poultry flocks in the study region in addition to internal organs (liver, spleen, intestine) collected at necropsy of suspected chickens belonging to small family enterprises. The samples were analyzed by conventional bacteriological methods (ISO 6579:2002/A1:2007) for isolation, and genus specific (invA) PCR for the identification of Salmonella spp. Then, two mPCR were set up to determine Salmonella serotypes and genotypic resistance status of the field isolates against ampicillin, tetracycline, trimethoprim-sulfamethoxazole and chloramphenicol antibiotics. In the PCR analysis of the suspected colonies, $98.5 \%$ were confirmed as Salmonella spp., and, the most prevalent serotype was identified as S. Infantis with the proportion of 26.6\% (17/64), followed by S. Enteritidis with 21.9\% (14/ 64) and S. Typhimurium with $9.4 \%$ (6/64). The findings related to antibiotic resistance genes revealed that the most frequently determined gene was sul 1 with approximately 58\%, while the blaTEM gene was detected at the lowest proportion with $20 \%$, among Salmonella isolates.
\end{abstract}

Conclusions: The results indicated that Salmonella infections constitute a potential risk for chicken flocks in the country and that genotypic resistance rates against various antibiotics should draw particular attention in terms of both human and animal health.

Keywords: Salmonella, Chicken, mPCR characterization, Antibiotic resistance profiling

\section{Background}

Salmonella has been described as one of the most common foodborne pathogens worldwide leading to outbreaks of gastroenteritis in humans [1]. In epidemiological studies, food supplies of animal origin, in particular poultry, have been reported to be the main carriers of Salmonella infections to humans [2-4]. Salmonella agents often cause infections in humans by forming biofilms and contaminating food products by clustering on the surfaces of food and

\footnotetext{
* Correspondence: bcetinkaya@firat.edu.tr

${ }^{2}$ Department of Microbiology, Veterinary Faculty, Firat University, 23100 Elazig, Turkey

Full list of author information is available at the end of the article
}

other materials [5]. Salmonella agents that cause infection in humans have been shown to be more common in poultry than in other animal species [6]. The presence of Salmonella in chicken meat and the other products may lead people to feel insecure about their consumption. Prevalence of Salmonella in chickens varies considerably between the countries. Field and abattoir based studies carried out in European countries revealed proportions ranging from 4 to $29 \%$ [7], while prevalence values ranging from 0.4 to $39 \%$ have been reported in different parts of Turkey [8-10].

Periodic identification of Salmonella serotypes circulating in poultry flocks is significant in terms of developing

\section{$\triangle B M C$}

(c) The Author(s). 2020 Open Access This article is licensed under a Creative Commons Attribution 4.0 International License, which permits use, sharing, adaptation, distribution and reproduction in any medium or format, as long as you give appropriate credit to the original author(s) and the source, provide a link to the Creative Commons licence, and indicate if changes were made. The images or other third party material in this article are included in the article's Creative Commons licence, unless indicated otherwise in a credit line to the material. If material is not included in the article's Creative Commons licence and your intended use is not permitted by statutory regulation or exceeds the permitted use, you will need to obtain permission directly from the copyright holder. To view a copy of this licence, visit http://creativecommons.org/licenses/by/4.0/ The Creative Commons Public Domain Dedication waiver (http://creativecommons.org/publicdomain/zero/1.0/) applies to the data made available in this article, unless otherwise stated in a credit line to the data. 
strategies for control and prevention of the disease and thereby for the trade of poultry products. Conventional detection of Salmonella agents is made by standard bacteriological culture method based on ISO 6579 protocols which takes 3 to 8 days. Although this method has been considered as the gold standard for the detection of Salmonella, owing to the time consumption researchers have preferred molecular based methods with high sensitivity and specificity such as polymerase chain reaction (PCR) in recent years [11-13]. Molecular studies on Salmonella have targeted different gene regions such as invA [14], iroB [15], spiC [16], pipD [17] and int1 [18], and the results showed that the target gene region significantly affects the identification rates. The invA gene plays an important role in virulence of Salmonella agents and invasion into host cells [19]. In addition, the presence of the $\operatorname{inv} A$ gene in all Salmonella species has led to its use as a gold marker in molecular based diagnostic studies to date [20].

Antibiotic resistance, which has become a global problem due to unconscious and uncontrolled use, makes treatment and control of Salmonella infections difficult as well as other bacterial diseases. In order to investigate antibiotic resistance levels, both genotypic methods that demonstrate the presence of genes causing resistance, and phenotypic methods such as disk diffusion method are used. It is known that multidrug resistance (MDR) in Salmonella strains is of zoonotic origin and thus can be transferred from animals to humans through consumption of contaminated products $[21,22]$. Therefore, the determination of antibiotic resistance profiles in field isolates is important for revising the relevant legislations and developing more effective national strategies for preventing antibiotic resistance.

The aim of this study was to obtain quantitative data about the frequency, genotypic characterization and antibiotic resistance profiling of Salmonella agents in chicken flocks located in Elazig and the surrounding area.

\section{Results}

Salmonella suspected colonies were determined in $84.4 \%$ $(65 / 77)$ of the sock swab and internal organ samples which were subjected to isolation steps by ISO 6579 : 2002/A1:2007 method. Isolation was made from 75.5\%
(37/49) of the sock swabs collected in commercial poultry flocks, and from the internal organ samples of all $(n=28)$ necropsied animals belonging to small family enterprises. As a result of PCR analysis combined with a pair of primers specific to invA gene, 64 isolates produced amplification products at the molecular size of approximately $796 \mathrm{bp}$ which is considered as indicative for the presence of Salmonella spp. One isolate obtained from the sock swab collected in a commercial layer flock could not be confirmed as Salmonella spp. in the PCR. Thus, the presence of Salmonella agents was confirmed in $36(73.5 \%)$ of 49 poultry flocks ( 28 broiler and 8 layer) where sock swab samples were collected. In addition, all the isolates obtained from necropsied animals were found to be positive for Salmonella spp. by PCR (Table 1).

In the mPCR analysis of DNA samples extracted from 64 Salmonella spp. isolates, $S$. Infantis, $S$. Enteritidis and $S$. Typhimurium were identified in 17 (26.6\%), 14 (21.9\%) and 6 (9.4\%) of the isolates, respectively. The difference between the identification proportions of Salmonella serotypes was statistically significant $(p<0.05)$. The remaining 27 Salmonella isolates could not be typed with the serotype-specific primers employed in this study. All the Salmonella isolates obtained from layer flocks were identified as $S$. Infantis, while $S$. Enteritidis could not be detected in any of the commercial flocks. The mPCR results of the isolates obtained from the chicken samples were presented in Table 1.

In order to determine the presence of antibiotic resistance genes, Salmonella isolates obtained in the present study were subjected to MPCR combined with primer pairs specific to resistance genes of four different antibiotics. All the $S$. Infantis isolates were found to harbor the tet $A$ and sul1 genes encoding tetracycline and trimethoprim-sulfamethoxazole resistance respectively, while only two contained resistance gene specific to ampicillin. It was determined that in two of $S$. Typhimurium isolates, genes encoding ampicillin and trimethoprim/sulfamethoxazole resistance were present, whereas four of them comprised the resistance gene specific to ampicillin alone. On the other hand, only one $S$. Enteritidis isolate was determined to contain the

Table 1 Genotypic characterization of Salmonella isolates obtained from chicken samples

\begin{tabular}{|c|c|c|c|c|c|}
\hline \multirow[t]{2}{*}{ Sample Type } & \multirow{2}{*}{$\begin{array}{l}\text { Number } \\
\text { of invA-PCR } \\
\text { Positive Samples }\end{array}$} & \multicolumn{4}{|l|}{ mPCR Findings } \\
\hline & & $\begin{array}{l}\text { S. Typhimurium } \\
\text { (\%) }\end{array}$ & $\begin{array}{l}\text { S. Enteritidis } \\
(\%)\end{array}$ & $\begin{array}{l}\text { S. Infantis } \\
(\%)\end{array}$ & $\begin{array}{l}\text { Salmonella spp } \\
(\%)\end{array}$ \\
\hline \multicolumn{6}{|l|}{ Sock Swabs } \\
\hline Broiler $(n=39)$ & 28 & $6(21.4)$ & - & $9(32.1)$ & $13(46.4)$ \\
\hline Layer $(n=10)$ & 8 & - & - & $8(100)$ & - \\
\hline Internal Organs & 28 & - & $14(50)$ & - & $14(50)$ \\
\hline Total & 64 & $6(9.4)$ & $14(21.9)$ & $17(26.6)$ & $27(42.2)$ \\
\hline
\end{tabular}


resistant genes specific to ampicillin, tetracycline and trimethoprim/sulfamethoxazole antibiotics, the rest of the isolates belonging to this serotype were not positive for the resistance genes tested in this study. Of the 27 Salmonella spp. isolates which could not be characterized with the serotype specific primers here, 17 were detected to harbor the resistance gene encoding trimethoprim/ sulfamethoxazole, and four were positive for the ampicillin and tetracycline resistance genes (Table 2). However, none of the isolates obtained in the current study were determined to possess the cat1 gene encoding chloramphenicol resistance. Overall evaluation of the antibiotic resistance profiling findings revealed that the most frequently determined gene was sul1 encoding trimethoprim/sulfamethoxazole resistance with approximately $58 \%$, while the blaTEM gene encoding ampicillin resistance was detected at the lowest proportion with 20\%, among Salmonella isolates. The difference between these proportions was statistically significant $(p<0.05)$.

DNA samples belonging to 13 randomly selected isolates among Salmonella spp. isolates which could not be typed with the specific primers used in the present study were subjected to sequence analysis. As a result of BLAST analysis, high similarity (99-100\%) was detected between the partially sequenced isolates and Salmonella enterica subsp. enterica serovar Mbandaka strain CFSAN076213 (GenBank Accession Number: CP033343.1).

\section{Discussion}

The expenses due to treatment and prevention of Salmonella infections in both poultry and humans impose great economic burden all over the world. For instance, the annual cost for the treatment of poultry originated Salmonella infections in the USA has been calculated to be as much as 14 billion dollars [23]. It is therefore an urge to develop effective control, eradication and prevention strategies toward Salmonella infections in both poultry and humans. In this respect, large scaled epidemiological investigations of diseases caused by Salmonella may provide useful data. From this point of view, this study was carried out to obtain quantitative data about the presence and frequency of Salmonella species circulation in chicken flocks in Turkey. Also, considering the fact that antibiotic resistance has become a global concern due unconscious and uncontrolled use which makes treatment and control of bacterial infection difficult, genotypic resistance profiling of the field isolates against various commonly used antibiotics was investigated in the present study.

Many studies have been conducted to reveal the presence and distribution of Salmonella species in chicken, worldwide and the prevalence rates ranging from 4 to $92 \%$ have been reported [24, 25]. On the other hand, field and abattoir based studies carried out different regions of Turkey have declared the proportions ranging from 0.4 to $39 \%$ [8-10]. In the analysis of sock swabs and internal organ samples collected from the total of 77 chicken flocks in the present study, Salmonella spp. identification was confirmed by PCR in 64 which corresponded to $83.1 \%$ overall. Many parameters such as geographical location, prevention/control and biosafety measures of the flocks, breeding conditions (cage/ground), flock management styles, sample size, sample type (drag swab, bedding, feces, internal organ, cloacal swab etc), sampling season and isolation and identification methods may be responsible in the occurrence of remarkably different isolation rates.

Sample type is considered as one of the significant parameters that play role in obtaining remarkable different results in terms of the frequency of Salmonella. In this study, sock swabs was preferred to collect fecal samples representing at least $20 \%$ of the flock area instead of collecting individual samples, considering its advantages such as being more practical, representing the whole flock, saving labor and time in addition to enhancing isolation chance and rate. In fact, the isolation rate obtained from the fecal samples in this study was remarkably high (73.5\%) when compared with the report (7\%) of Aksakal (2003) who examined cloacal swab samples collected from chickens in Van province [26]. This difference is not surprising because it has previously been reported that isolation chance of Salmonella from cloacal swabs might be decreased due to intermittent shedding in feces [27]. Similarly, Berghaus et al. [28] obtained $90 \%$ isolation rate from fecal samples collected via boot swab method which is similar to that used in the current study [28]. Also, in a study carried out in Spain, it was showed that while the isolation rate of Salmonella was $4 \%$ in cloacal swab

Table 2 mPCR results of antibiotic resistance profiling of Salmonella isolates obtained from chicken samples

\begin{tabular}{|c|c|c|c|c|c|}
\hline \multirow[t]{2}{*}{ Antibiotics } & \multicolumn{5}{|c|}{ mPCR results of Salmonella isolates } \\
\hline & $\begin{array}{l}\text { Salmonella } \\
\text { Typhimurium }\end{array}$ & $\begin{array}{l}\text { Salmonella } \\
\text { Enteritidis }\end{array}$ & $\begin{array}{l}\text { Salmonella } \\
\text { Infantis }\end{array}$ & Salmonella spp. & Total (\%) \\
\hline Tetracycline & - & 1 & 17 & 4 & $22(34.4)$ \\
\hline Trimethoprim/Sulfamethoxazole & 2 & 1 & 17 & 17 & $37(57.8)$ \\
\hline Ampicillin & 6 & 1 & 2 & 4 & $13(20.3)$ \\
\hline Chloramphenicol & - & - & - & - & - \\
\hline
\end{tabular}


samples, remarkably high percentage (92\%) was obtained in the examination of feces samples collected using a sterile tongue depressor [24]. These studies put forward that sample collection method has a direct effect on the isolation rate of Salmonella.

An increase of $1{ }^{\circ} \mathrm{C}$ in the global temperature has been reported to enhance incidence of Salmonella which suggested that there may be a correlation between temperature and incidence of the disease [29]. In this study, the collection of fecal samples in July and August in which the temperature is very high may play a role in obtaining high isolation rate. Likewise, over $50 \%$ isolation rate has been reported in a field study conducted in Adana province which has one of the highest annual temperature in Turkey [10].

In most of the studies carried out in chickens all over the world, $S$. Enteritidis and $S$. Infantis have been reported to be more commonly identified serotypes than the others [20, 30-33]. Also, according to 2016 EFSA report, $S$. Infantis (37\%) was the most commonly reported Salmonella serotype in broiler flocks, followed by $S$. Enteritidis (14\%) [34]. In Turkey, previous studies based on conventional serotyping reported varied results in terms of the frequency of Salmonella agents depending on the study region and sample type but, overall evaluation of these studies showed that most commonly identified serotypes in chicken flocks were $S$. Enteritidis, $S$. Typhimurium and $S$. Infantis $[9,10,26,35-39]$. In the present study, mPCR analysis of Salmonella sp. isolates revealed that $S$. Infantis, (26.6\%) and $S$. Enteritidis (21.9\%) were the most prevalent species followed by $S$. Typhimurium (9.4\%). Although $S$. Infantis and $S$. Enteritidis isolation rates were close to each other, $S$. Infantis was found only in sock swab samples while $S$. Enteritidis in internal organ samples. The high isolation of $S$. Enteritidis from internal organs may be due to the fact that it is more invasive than other paratyphoid agents. On the other hand, $S$. Infantis has been shown to act as asymptomatic carrier in chickens and contaminate the environment as well as foods [40, 41]. Therefore, detection of $S$. Infantis as the most common serotype in this study was considered as an expected result. There are studies reporting the presence of other Salmonella species (S. Kentucky, S. Hadar, S. Liverpool, etc.) in poultry feces and internal organs [39]. The serotypes mentioned above were not included in this study because of the budget constraint, while $S$. Pullorum and $S$. Gallinarum were subject to the permission of the Food and Control General Directorate of Agriculture Ministry. However, partial sequence analysis of 13 randomly selected isolates that could not be typed in this study, showed very close homology with the strain of $S$. Mbandaka CFSAN076213 in the GeneBank.

The widespread use of antibiotics for promoting growth and prophylactic purpose in poultry flocks has led to bacterial resistance to antimicrobial agents [42]. Therefore, determination of resistance of Salmonella agents circulating in poultry farms to antibiotics commonly used in the market is important in terms of developing more effective treatment and control strategies. Many studies have been conducted to determine antibiotic resistance profiles of Salmonella agents in chickens worldwide, and resistance against many different antibiotics has been reported in chicken originated field isolates [4, 31, 32, 43]. According to EFSA report in 2016, among 2288 Salmonella isolates obtained from chicken flocks in the European Union, the highest resistance (between 40 and 50\%) was detected against nalidixic acid, sulfamethoxazole and tetracycline antibiotics, whereas moderate and low resistance was noted against ampicillin (19\%) and chloramphenicol (4\%), respectively. When EFSA data were evaluated at serotype level, $S$. Infantis isolates had high resistance to nalidixic acid, sulfamethoxazole and tetracycline (over $80 \%$ ), whereas the highest resistance among S. Enteritidis isolates were determined against nalidixic acid with $23 \%$. On the other hand, high levels of resistance to tetracycline and ampicillin have been reported in $S$. Thyphimurium isolates obtained from laying hens [34]. Antibiotic resistance status of Salmonella species has been studied in Turkey as well, mostly based on phenotypical methods. In a number of studies carried out in different parts of Turkey, Salmonella isolates obtained from samples collected in both chicken flocks and slaughterhouses were reported to show the highest resistance against ampicillin $[9,10,26,35,41]$. The only molecular based study carried out in Sanliurfa province of Turkey so far, has reported that $S$. Infantis isolates obtained from various food sources showed high resistance against tetracycline and sulfonamide [44].

Among the 64 field isolates obtained in this study, the sul1 gene was determined at the highest proportion with $57.8 \%$, which was followed by tet $A$ with $34.4 \%$ and blaTEM with $20.3 \%$. On the other hand, none of the isolates were found to harbor cat1 gene. When the antibiotic resistance profiles were considered at serotype level, all the $S$. Infantis isolates were detected to contain resistance genes encoding tetracycline and trimethoprim- sulfamethoxazole, whereas $S$. Typhimurium isolates were positive for the ampicillin resistance gene. When the genotypic resistance rates obtained in this study were evaluated in general, there was a similarity with the 2016 report of EFSA [34], but the presence of resistance gene specific to ampicillin was lower than the previous studies conducted in different regions of Turkey. Although many studies carried our elsewhere reported high resistance rate against nalidixic acid, it was not included in this study due to the fact that it is not used in the enterprises located in the study region. Also, other antibiotics tested in previous studies were beyond the scope of 
the present study due to budget limitations. Regional differences, antibiotic choice of the enterprise, methodology used for resistance detection and the number of isolates tested might be responsible for obtaining different resistance or susceptibility results against the same antibiotic. All in all, both literature data and the results obtained here suggest that antibiotic resistance in Salmonella species continue to pose a major problem in Turkey and elsewhere.

\section{Conclusion}

In conclusion, the findings that Salmonella agents were isolated and identified from more than $70 \%$ of the flocks where sock swab samples were collected and that $S$. Infantis, $S$. Enteritidis and $S$. Typhimurium were detected to be the most dominant subtypes in the study region suggest that Salmonella infections constitute a potential risk for chicken flocks in the country. In addition, the results concerning genotypic resistance profiles of the isolates against various antibiotics in this and previous studies should draw particular attention in terms of both human and animal health. Antibiotic susceptibility testing before the selection of antibiotics for the treatment of Salmonella infections is therefore important in preventing unconscious and random use of antibiotics and minimizing the development of resistance in strains.

\section{Methods}

\section{Sampling}

Feces samples were collected from 49 different commercial chicken farms (39 broiler and 10 layer hens) in Elazig province and its surroundings located in eastern Turkey, between July and August 2018 with the help of sock swabs. The broiler flocks had the capacity ranging from 15.000 to 38.000 birds at the average age of 25 days, while the capacity of the layer flocks was between 3.000 and 10.000 birds at the average age of 32 weeks. All the commercial farms had ground type husbandry system. When collecting faecal samples via sock swabs, at least $20 \%$ of the flock area were considered as representative of the farm. In addition, internal organ (liver, spleen and cecum) samples taken at necropsy of 28 Salmonella suspected chickens belonging to small family enterprises in the region were included in the study. These animals were dispatched from the local family farms where few deaths have been reported. The animal capacity of the family enterprises showed a wide range from 12 to 2500 birds at the age of $>20$ weeks. Fecal and internal organ samples were transported under aseptic conditions and cold chain to the laboratories of Department of Veterinary Microbiology, Firat University and, were examined for Salmonella.

\section{Isolation and identification of Salmonella}

Isolation and identification of Salmonella species were performed according to ISO 6579: 2002/ Amd 1:2007 standard method [45]. For this purpose, inoculation steps to pre-enrichment, selective enrichment and selectivedifferential culture media were carried out. Each of the sock swabs and the internal organ samples (pooled to be $25 \mathrm{~g}$ ) were homogenized with $250 \mathrm{ml}$ sterile Buffered Peptone Water (BPW, 10\%) and incubated at $37^{\circ} \mathrm{C}$ for 18-24 h. For selective enrichment, $0.1 \mathrm{ml}$ from the second day culture following pre-enrichment was transferred to two tubes, one containing $10 \mathrm{ml}$ Rappaport-Vassiliadis Soy Broth (RVS) and the other containing $10 \mathrm{ml}$ Muller Kauffmann Tetrathionate-Novobiocin Broth, and the tubes were incubated at $42^{\circ} \mathrm{C}$ for $18-24 \mathrm{~h}$. On the third day after incubation, a loopful of culture was inoculated with streaking plate method onto Brilliant Green Agar (BGA), Xylose Lysine Deoxycholate (XLD) Agar and MacConkey Agar for isolation and was incubated at $37^{\circ} \mathrm{C}$ for 24-48 h. Salmonella suspected colonies (red with black centers in XLD agar, pink in BGA and colorlesstransparent in MacConkey Agar) were purified in Nutrient Agar and were stored at $-20^{\circ} \mathrm{C}$ in Nutrient Broth containing $20 \%$ glycerol for molecular analyses.

\section{DNA extraction}

For the identification and molecular characterization of Salmonella, DNA extraction was carried out from cultures stored in Nutrient Broth. For this, suspected isolates were inoculated onto Nutrient Agar and were incubated at $37^{\circ} \mathrm{C}$ for one day. Suspected colonies (7-8) were transferred to Eppendorf tubes containing $300 \mu \mathrm{l}$ of distilled water and were homogenized. Each suspension was treated with $300 \mu \mathrm{l}$ TNES buffer and $6 \mu$ l Proteinase $\mathrm{K}(20 \mathrm{mg} / \mathrm{ml})$, and then inactivated at $56^{\circ} \mathrm{C}$ for $2 \mathrm{~h}$. After the suspension was boiled for $10 \mathrm{~min}, 400 \mu \mathrm{l}$ phenol (saturated with Tris- $\mathrm{HCl}$ ) was added and the mixture was shaken for $10 \mathrm{~min}$ followed by spinning at $11.600 \mathrm{~g}$ for $10 \mathrm{~min}$. The upper phase was carefully transferred to another Eppendorf tube without touching phenol phase, and then DNA precipitation was performed. For this purpose, $30 \mu \mathrm{l}$ of $3 \mathrm{M} \mathrm{Na}$-acetate $(0.1$ volume) and $750 \mu \mathrm{l}$ of pure alcohol (2.5 volume) were added to the suspension which was vortexed and kept at $20^{\circ} \mathrm{C}$ overnight. The suspension was then centrifuges at $11.600 \mathrm{~g}$ for $10 \mathrm{~min}$, and the supernatant was carefully removed. The resulting pellet was washed with $70 \%$ ethanol and centrifuged at $11.600 \mathrm{~g}$ for $5 \mathrm{~min}$. The final pellet was allowed to dry for $45 \mathrm{~min}$ and was suspended in $10 \mu \mathrm{l} \mathrm{ster-}$ ile distilled water. This suspension was used as target DNA in molecular analyzes.

Polymerase chain reaction (PCR) and multiplex PCR (mPCR) For the identification of Salmonella at genus level, PCR mixture was prepared in total volume of $25 \mu \mathrm{l}$ containing $2.5 \mu \mathrm{l}$ 10xPCR buffer, $2.5 \mu \mathrm{l} 25 \mathrm{mM} \mathrm{MgCl}_{2}, 2 \mu \mathrm{l}$ dNTP Set, $0.25 \mu \mathrm{l} 5 \mathrm{U} / \mu \mathrm{l}$ Taq DNA Polymerase enzyme, $1 \mu \mathrm{l}$ of each of the genus-specific primer pair (Table 3) (20 
Table 3 Primers used for the detection of Salmonella serotypes and antibiotic resistance genes in chicken isolates

\begin{tabular}{|c|c|c|c|c|}
\hline Agent/ Antibiotics & Gene & Primer sequences & Fragment size (bp) & Literature \\
\hline \multirow[t]{2}{*}{ Salmonella sp. } & $\operatorname{inv} A-\mathrm{F}$ & CGGTGGTTITAAGCGTACTCTT & \multirow[t]{2}{*}{796} & \multirow[t]{2}{*}{ [14] } \\
\hline & invA-R & CGAATATGCTCCACAAGGTTA & & \\
\hline \multirow{2}{*}{$\begin{array}{l}\text { Salmonella } \\
\text { Typhimurium }\end{array}$} & Salflic-F & CCCCGCTTACAGGTGGACTAC & \multirow[t]{2}{*}{433} & \multirow[t]{2}{*}{ [20] } \\
\hline & Salflic-R & AGCGGGTTITCGGTGGTTGT & & \\
\hline \multirow[t]{2}{*}{ Salmonella Enteritidis } & SdfIII-F & GCTGACTCACACAGGAAATCG & \multirow[t]{2}{*}{350} & \multirow[t]{2}{*}{ [46] } \\
\hline & SdfIII-R & TCTGATAAGACTGGGTTTCACT & & \\
\hline \multirow[t]{2}{*}{ Salmonella Infantis } & FljB-F & TTGCTTCAGCAGATGCTAAG & \multirow[t]{2}{*}{413} & \multirow[t]{2}{*}{ [47] } \\
\hline & FljB-R & CCACCTGCGCCAACGCT & & \\
\hline \multirow[t]{2}{*}{ Ampicillin } & blaTEM-F & CATTCCGTGTCGCCCTTAT & \multirow[t]{2}{*}{793} & \multirow[t]{2}{*}{ [48] } \\
\hline & blaTEM-R & TCCATAGTTGCCTGACTCCC & & \\
\hline \multirow[t]{2}{*}{ Tetracycline } & tetA-F & GCTACATCCTGCTTGCCTTC & \multirow[t]{2}{*}{210} & \multirow[t]{2}{*}{ [49] } \\
\hline & tetA-R & CATAGATCGCCGTGAAGAGG & & \\
\hline \multirow[t]{2}{*}{ Trimethoprim-Sulfamethoxazole } & sul1-F & TCACCGAGGACTCCTTCTTC & \multirow[t]{2}{*}{316} & \multirow[t]{2}{*}{ [48] } \\
\hline & sul1-R & AATATCGGGATAGAGCGCAG & & \\
\hline \multirow[t]{2}{*}{ Chloramphenicol } & cat1-F & CTTGTCGCCTTGCGTATAAT & \multirow[t]{2}{*}{508} & \multirow[t]{2}{*}{ [50] } \\
\hline & cat1-R & ATCCCAATGGCATCGTAAAG & & \\
\hline
\end{tabular}

pmol), $1 \mu \mathrm{l}$ of target DNA and $14.75 \mu \mathrm{l}$ of DNase-RNase free water.

In order to identify Salmonella isolates at species level and to determine resistance status to various antibiotics, mPCR was performed. For this purpose, PCR mixtures in a total volume of $33 \mu \mathrm{l}$ was prepared which contained $2.5 \mu \mathrm{l} 10 \mathrm{x}$ PCR buffer, $2.5 \mu \mathrm{l} 25 \mathrm{mM} \mathrm{MgCl} 2,2 \mu \mathrm{l} \mathrm{dNTP}$ Set, $0.25 \mu \mathrm{l} 5 \mathrm{U} / \mu \mathrm{l}$ Taq DNA Polymerase enzyme, $1 \mu \mathrm{l}$ $(20 \mathrm{pmol})$ of each primer pairs specific for Salmonella species and antibiotic resistance genes (Table 3), $1 \mu \mathrm{l}$ target DNA and 10.75 DNase-RNase free water.

The amplified PCR products were electrophoresed on a $1.5 \%$ agarose gel containing $10 \mu \mathrm{l}$ of Ethidium Bromide solution, then examined under Ultraviolet transilluminator and the results were observed and photographed with Polaroid GelCam. A 100 bp DNA ladder was used to determine the molecular weight of the resulting bands. Following agarose gel electrophoresis, PCR products with the molecular sizes of approximately $796 \mathrm{bp}, 433 \mathrm{bp}, 413 \mathrm{bp}$ and $350 \mathrm{bp}$ were considered as indicative for Salmonella spp., $S$. Typhimurium, $S$. Infantis and $S$. Enteritidis, respectively. In addition, mPCR analysis for the presence of antibiotic resistance genes yielded products at the molecular sizes of approximately $793 \mathrm{bp}$ for ampicillin, $508 \mathrm{bp}$ for chloramphenicol, $316 \mathrm{bp}$ for trimethoprim/sulfamethoxazole and $210 \mathrm{bp}$ for tetracycline. In order to detect any possible contamination at any stage of the study, DNA samples belonging to Salmonella Typhimurium (NCTC- National Collection of Type Cultures- London, UK, 74), Salmonella Enteritidis ([NCTC, London, UK 12694) and Salmonella Infantis (Etlik Veterinary Control Research Center, Poultry Diseases Diagnostic Laboratory Collection) were used as positive controls, and DNase-RNase free water were used as negative control in both DNA extraction steps and PCR assays.

\section{Sequencing}

DNA samples belonging to randomly selected 13 isolates, which were confirmed as Salmonella spp., but were not amplified by species specific primers employed in this study, were amplified with primers specific to $\operatorname{inv} A$ gene and sent to Istanbul Pendik Veterinary Control Institute for partial sequence analysis in $\mathrm{ABI} 3130 \mathrm{XL}$ genetic analyser (USA).

\section{Statistical analysis}

The differences between the identification rates of Salmonella species and the proportion of resistance genes to antibiotics included in the study were evaluated by chi square $(\mathrm{x} 2)$ test and probability values of $P<0.05$ were considered statistically significant.

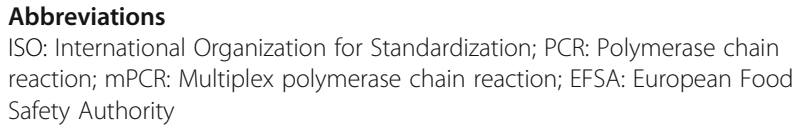

ISO: International Organization for Standardization; PCR: Polymerase chain reaction; $\mathrm{mPCR}$ : Multiplex polymerase chain reaction; EFSA: European Food Safety Authority

\section{Acknowledgements}

This study which was part of an MSc thesis produced by Aydogan Arkali.

\section{Authors' contributions}

Sample collection, methodology, analysis, writing- review and editing: AA and $\mathrm{BC}$. All authors have read and approved the manuscript.

\section{Funding}

This work was part of an MSc thesis which was only financially funded by the Scientific Research and Projects Unit of Firat University (FUBAB VF.18.12). 
They had no role in the design of the study and collection, analysis, and interpretation of data and in writing the manuscript.

\section{Availability of data and materials}

The datasets used and/or analysed during the current study are available from the corresponding author on reasonable request.

\section{Ethics approval and consent to participate}

This study was approved by the local Ethics Committee of Firat University in the meeting dated 04.04 .2018 with the decision number 2018/06-73. The informed verbal consent was obtained from all participating farm owners prior to sample collection and this was approved by the ethics committee.

\section{Consent for publication}

Not applicable.

\section{Competing interests}

The authors declare that they have no competing interests.

\section{Author details}

${ }^{1}$ Veterinary Control Institute, 23100 Elazig, Turkey. ${ }^{2}$ Department of Microbiology, Veterinary Faculty, Firat University, 23100 Elazig, Turkey.

Received: 14 February 2020 Accepted: 11 June 2020

Published online: 19 June 2020

\section{References}

1. Humphrey T. Public health aspects of Salmonella infection. In: Wray C, Wray A, editors. Salmonella in domestic animals. Wallingford: CABI Publishing; 2000. p. 245-62.

2. Zhao S, McDermott PF, Friedman S, Qaiyumi S, Abbott J, Kiessling C, Ayers S, Singh R, Hubert S, Sofos J, White DG. Characterization of antimicrobial-resistant Salmonella isolated from imported foods. J Food Prot. 2006;69:500-7.

3. Dallal MMS, Doyle MP, Rezadehbashi M, Dabiri H, Sanaei M, Modarresi S, Bakhriari R, Sharifiy K, Taremi M, Zali MR, Sharifi-Yazdi MK. Prevalence and antimicrobial resistance profiles of Salmonella serotypes, Campylobacter and Yersinia spp. isolated from retail chicken and beef, Tehran, Iran. Food Control. 2010;21:388-92.

4. Velasquez CG, MacKlin KS, Kumar S, Bailey M, Ebner PE, Oliver HF, MartinGonzalez FS, Singh M. Prevalence and antimicrobial resistance patterns of Salmonella isolated from poultry farms in southeastern United States. Poult Sci. 2018;97:2144-52

5. Chia TWR, Goulter RM, McMeekin T, Dykes GA, Fegan N. Attachment of different Salmonella serovars to materials commonly used in a poultry processing plant. Food Microbiol. 2009;26:853-9.

6. Foley SL, Nayak R, Hanning IB, Johnson TJ, Han J, Ricke SC. Population dynamics of Salmonella enterica serotypes in commercial egg and poultry production. Appl Environ Microbiol. 2011;77:4273-9.

7. European Food Safety Authority (EFSA). Analysis of the baseline survey on the prevalence of Campylobacter in broiler batches and of Campylobacte and Salmonella on broiler carcasses in the EU,2008-Part A: Campylobacter and Salmonella prevalence estimates. EFSA J. 2010;8:1522.

8. Kaan Yilmaz O. Isolation of Salmonella spp. from slaughtered poultry and equipment in slaughterhouses in Aydin region and the results of antibiotic susceptibility tests of Salmonella isolates. MSc Thesis, Aydin Adnan Menderes Univ. Sagl Bil Enst. 2001:1-36.

9. Kahya S, Kesin Tug B, Temelli S, Carli KT, Eyigor A. Detection of Salmonella from layer flocks and typing of the isolates. Kafkas Univ Vet Fak Derg. 2014; 20:939-44.

10. Incili GK, Koluman A, Dikici A, Kahraman T, Unlu AT. Characterization of Salmonella isolated from organically reared poultry located in the same longitude with three distinct seasonal characteristics. J Food Saf. 2019:39:1-8.

11. Myint MS, Johnson YJ, Tablante NL, Heckert RA. The effect of preenrichment protocol on the sensitivity and specificity of PCR for detection of naturally contaminated Salmonella in raw poultry compared to conventional culture. Food Microbiol. 2006:23:599-604.

12. Wise MG, Siragusa GR, Plumblee J, Healy M, Cray PJ, Seal BS. Predicting Salmonella enterica serotypes by repetitive sequence-based PCR. J Microbiol Methods. 2009;76:18-24.
13. Heymans R, Vila A, van Heerwaarden CAM, Jansen CCC, Castelijn GAA, van der Voort M, Biesta-Peters EG. Rapid detection and differentiation of Salmonella species, Salmonella Typhimurium and Salmonella Enteritidis by multiplex quantitative PCR. PLoS One. 2018;13(10):1-15.

14. Fratamico PM. Comparison of culture, polymerase chain reaction (PCR),taqman Salmonella, and transia card Salmonella assays for detection of Salmonella spp. in naturally-contaminated ground chicken, ground turkey, and ground beef. Mol Cell Probes. 2003;17:215-21.

15. Bäumler AJ, Heffron F, Reissbrodt R. Rapid detection of Salmonella enterica with primers specific for iroB. J Clin Microbiol. 1997;35:1224-30.

16. Uchiya K, Nikai T. Salmonella virulence factor SpiC is involved in expression of flagellin protein and mediates activation of the signal transduction pathways in macrophages. Microbiology. 2008;154:3491-502.

17. Khoo CH, Sim JH, Salleh NA, Cheah YK. Pathogenicity and phenotypic analysis of $\operatorname{sop} B$, sopD and pipD virulence factors in Salmonella enterica serovar Typhimurium and Salmonella enterica serovar Agona. Antonie Van Leeuwenhoek. 2015:107:23-37.

18. Hughes LA, Shopland S, Wigley $P$, Bradon $H$, Leatherbarrow $A H$, Williams NJ, Bennett M, de Pinna E, Lawson B, Cunningham AA, Chantrey J. Characterisation of Salmonella enterica serotype Typhimurium isolates from wild birds in northern England from 20052006. BMC Vet Res. 2008;4:1-10.

19. Van Asten AJAM, Van Dijk JE. Distribution of "classic" virulence factors among Salmonella spp. FEMS Immunol Med Microbiol. 2005;44:251-9.

20. O'Regan E, McCabe E, Burgess C, McGuinness S, Barry T, Duffy G, Whyte P, Fanning $\mathrm{S}$. Development of a real-time multiplex PCR assay for the detection of multiple Salmonella serotypes in chicken samples. BMC Microbiol. 2008:8(156):1-11.

21. Campioni F, Moratto Bergamini AM, Falcão JP. Genetic diversity, virulence genes and antimicrobial resistance of Salmonella Enteritidis isolated from food and humans over a 24-year period in Brazil. Food Microbiol. 2012:32:254-64

22. Su JH, Zhu YH, Ren TY, Guo L, Yang GY, Jiao LG, Wang JF. Distribution and antimicrobial resistance of Salmonella isolated from pigs with diarrhea in China. Microorganisms. 2018;6(4):117.

23. Cosby DE, Cox NA, Harrison MA, Wilson JL, Buhr RJ, Fedorka-Cray PJ. Salmonella and antimicrobial resistance in broilers: a review. J Appl Poult Res. 2015:24:408-26.

24. García C, Soriano JM, Benítez V, Catala-Gregori P. Assessment of Salmonella spp. in feces, cloacal swabs, and eggs (eggshell and content separately) from a laying hen farm. Poult Sci. 2011;90:1581-5.

25. El-Sharkawy H, Tahoun A, El-Gohary AEGA, El-Abasy M, El-Khayat F, Gillespie T, Kitade Y, Hafez HM, Neubauer H, El-Adawy H. Epidemiological, molecular characterization and antibiotic resistance of Salmonella enterica serovars isolated from chicken farms in Egypt. Gut Pathog. 2017;9:1-12.

26. Aksakal A. The occurrence and prevalence Salmonella species in feces of certain fowls and their susceptibility to antibiotics. YYU Vet Fak Derg. 2003; 14:95-101.

27. Goncagul G, Carli KT. Tavuklardan Salmonella izolasyonunda kloakal swab ve drag swab metodlarinin karsilastirilmasi. Veterinarium. 1999;10:31-3.

28. Berghaus RD, Thayer SG, Law BF, Mild RM, Hofacre CL, Singer RS. Enumeration of Salmonella and campylobacter spp. in environmental farm samples and processing plant carcass rinses from commercial broiler chicken flocks. Appl Environ Microbiol. 2013;79:4106-14.

29. Kovats RS, Edwards SJ, Hajat S, Armstrong BG, Ebi KL, Menne B. The effect of temperature on food poisoning: a time-series analysis of salmonellosis in ten European countries. Epidemiol Infect. 2004;132:443-53.

30. Herrera-León S, McQuiston JR, Usera MA, Fields PI, Garaizar J, Echeita MA. Multiplex PCR for distinguishing the most common phase-1 flagellar antigens of Salmonella spp. J Clin Microbiol. 2004;42:2581-6.

31. Rahmani M, Peighambari SM, Svendsen CA, Cavaco LM, Agerso Y, Hendriksen RS. Molecular clonality and antimicrobial resistance in Salmonella enterica serovars Enteritidis and Infantis from broilers in three northern regions of Iran. BMC Vet Res. 2013:9(66):1-9.

32. Vinueza-Burgos C, Cevallos M, Ron-Garrido L, Bertrand S, De Zutter L. Prevalence and diversity of Salmonella serotypes in ecuadorian broilers at slaughter age. PLoS One. 2016;11(7):1-12.

33. Bai J, Trinetta V, Shi X, Noll LW, Magossi G, Zheng WL, Porter EP, Cernicchiaro N, Renter DG, Nagaraja TG. A multiplex real-time PCR assay, based on invA and pagC genes, for the detection and quantification of Salmonella enterica from cattle lymph nodes. J Microbiol Methods. 2018;148:110-6. 
34. European Food Safety Authority (EFSA). The European Union summary report on antimicrobial resistance in zoonotic and indicator bacteria from humans, animals and food in 2014. EFSA J. 2016;14(2):1-207.

35. Kutu A. Isolation, serotyping and investigation of antibiotic susceptibilities of Salmonella species in poultry. MSc Thesis, Aydin. Adnan Menderes Univ Saglik Bil Enst. 2017; 1-101.

36. Kalender H, Muz A. Tying of Salmonella spp. isolated from chickens in Elazig region. Tr J Vet Anim Sci. 1999;23:297-303.

37. Eyigor A, Goncagul G, Gunaydin E, Carli KT. Salmonella profile in chickens determined by real-time polymerase chain reaction and bacteriology from years 2000 to 2003 in Turkey. Avian Path. 2005;34:101-5.

38. Kilinc $U$, Aydin F. Antibiotic susceptibility of Salmonella spp isolated chicken from poultry enterprises in Kayseri region. J Health Sci. 2006;15:35-40.

39. Sahan O, Aral EM, Aden MMA, Aksoy A, Yilmaz O, Jahed R, Akan M. Distribution and antibiotic resistance of Salmonella isolates from broiler enterprices in Turkey. Ankara Univ Vet Fak Derg. 2016;63:1-6.

40. Shahada F, Chuma T, Tobata T, Okamoto K, Sueyoshi M, Takase K. Molecular epidemiology of antimicrobial resistance among Salmonella enterica serovar Infantis from poultry in Kagoshima, Japan. Int J Antimicrobial Agents. 2006; 28:302-7.

41. Hauser E, Tietze E, Helmuth R, Junker E, Prager R, Schroeter A, Rabsch W, Fruth A, Toboldt A, Malorny B. Clonal dissemination of Salmonella enterica serovar Infantis in Germany. Foodborne Path Dis. 2012;9:352-60.

42. Cogliani C, Goossens H, Greko C. Restricting antimicrobial use in food animals: lessons from Europe. Microbe. 2011;6:274-9.

43. Mendonça EP, de Melo RT, Nalevaiko PC, Monteiro GP, Fonseca BB, Galvao NN, Giombelli A, Rossi DA. Spread of the serotypes and antimicrobial resistance in strains of Salmonella spp. isolated from broiler. Braz J Microbiol. 2019:50:515-22

44. Acar S, Bulut E, Durul B, Uner I, Kur M, Avsaroglu MD, Kirmaci HA, Tel YO, Zeyrek FY, Soyer Y. Phenotyping and genetic characterization of Salmonella enterica isolates from Turkey revealing arise of different features specific to geography. Int J Food Microbiol. 2017;241:98-107.

45. International Organization for Standardization (ISO), 6579:2002/A1:2007. Microbiology of food and animal feeding stuffs-horizontal method for the detection of Salmonella spp. Amendment 1: Annex D: Detection of Salmonella spp. in animal faeces and in environmental samples from the primary production stage. 2007.

46. Agron PG, Walker RL, Kinde H, Sawyer SJ, Hayes DC, Wollard J, Andersen GL. Identification by subtractive hybridization of sequences specific for Salmonella enterica serovar Enteritidis. Appl Environ Microbiol. 2001;67:4984-91.

47. Ghoddusi A, Nayeri Fasaei B, Karimi V, Tamai IA, Moulana Z, Salehi TZ. Molecular identification of Salmonella Infantis isolated from backyard chickens and detection of their resistance genes by PCR. Iran J Vet Res. 2015;16:293-7

48. Randall LP, Cooles SW, Osborn MK, Piddock LJV, Woodward MJ. Antibiotic resistance genes, integrons and multiple antibiotic resistance in thirty-five serotypes of Salmonella enterica isolated from humans and animals in the UK. J Antimicrob Chemother. 2004;53:208-16.

49. Fonseca EL, Mykytczuk OL, Asensi MD, Reis EMF, Ferraz LR, Paula FL, Ng LK Rodrigues DP. Clonality and antimicrobial resistance gene profiles of multidrug-resistant Salmonella enterica serovar Infantis isolates from four public hospitals in Rio de Janeiro, Brazil. J Clin Microbiol. 2006;44:2767-72.

50. Chen S, Zhao S, White DG, Schroeder CM, Lu R, Yang HC, McDermott PF, Ayers S, Meng JH. Characterization of multiple-antimicrobial-resistant Salmonella Serovars isolated from retail meats. Appl Environ Microbiol. 2004;70:1-7.

\section{Publisher's Note}

Springer Nature remains neutral with regard to jurisdictional claims in published maps and institutional affiliations.

Ready to submit your research? Choose BMC and benefit from:

- fast, convenient online submission

- thorough peer review by experienced researchers in your field

- rapid publication on acceptance

- support for research data, including large and complex data types

- gold Open Access which fosters wider collaboration and increased citations

- maximum visibility for your research: over $100 \mathrm{M}$ website views per year

At $\mathrm{BMC}$, research is always in progress.

Learn more biomedcentral.com/submissions 